Il'inskiiî, I. M. (2006) Ponimanie kak tsel' obrazovaniia. Znanie. Ponimanie. Umenie, no. 1, pp. 5-15. (In Russ.).

Levin, A. S. Soobrazheniia k kontseptsii razvitiia programmy. Informika [online] Available at: http://informika.ru/text/magaz/newpaper/messedu/cour0010/1800.html (access date: 16.09.2009).

Iaroshevskii, M. G. (1977) Logika razvitiia nauki i nauchnaia shkola. In: Shkoly $v$ nauke / ed. by S. R. Mikulinskii, M. G. Iaroshevskii, G. Kreber and G. Shteiner. Moscow, Nauka. 524 p. Pp. 7-96.

Submission date: 10.11.2018.

Крылова Елена Борисовна - доктор экономических наук, заведующий кафедрой экономических и финансовых дисциплин Московского гуманитарного университета. Адрес: 111395, Россия, г. Москва, ул. Юности, д. 5, корп. 2. Тел.: +7 (499) 374-73-61. Эл. адрес: EKrylova@mosgu.ru

Krylova Elena Borisovna, Doctor of Economics, Head, Department of Economic and Financial Disciplines, Moscow University for the Humanities. Postal address: 5, Yunosti St., Moscow, Russian Federation, 111395. Tel.: +7 (499) 374-73-61. E-mail: EKrylova@mosgu.ru

DOI 10.17805/zpu.2018.4.30

\title{
Качество жизни в системе приоритетов безопасного национального развития
}

\author{
О. Ю. МИНЧЕНКОВА \\ МОСКОВСКИЙ ГУМАНИТАРНЫЙ УНИВЕРСИТЕТ
}

В статье рассматривается роль качества жизни в системе приоритетов безопасного национального развития. Выделены приоритеты социальной политики государства. Проведена оценка объема накопленного имущества в полярных группах и его потенциала. Определены специфические признаки бедности в России.

Ключевые слова: качество жизни; факторы качества жизни; национальная безопасность; социальная политика; приоритеты развития

\begin{abstract}
$\Lambda$ юбая стратегия безопасности разрабатывается на основе выделения базовых национальных интересов и ценностей. Система национальных интересов имеет, с одной стороны, общий, универсальный характер, присущий всем странам, с другой - уникальный, специфический, свойственный лишь отдельным государствам набор элементов. Эта система развивается в результате эволюционного развития интересов ее подсистем, их взаимосвязей, а также внешнего воздействия. Степень организованности системы определяется количеством и разнообразием взаимосвязей ее әлементов. При высокой степени организованности система является достаточно стабильной, она мало зависит от внешних возбуждений, хотя изменение любого ее элемента может привести к изменению других элементов или системы в целом.

Формирование системы национальных интересов требует четкого определения жизненно важных интересов личности и общества, поскольку они при определенных условиях могут вступать в противоречие, которое может привести к возникновению и обострению угроз национальной безопасности. Однако национальную безопас-
\end{abstract}


ность не следует понимать только в контексте минимизации угроз жизненно важным интересам нации, она также должна включать условия существования социального субъекта, ориентиры будущего развития общества, механизмы обеспечения высокого уровня жизни. А ориентация только на настоящее не позволяет определить перспективы развития социальной сферы, пути и механизмы предупреждения угроз.

Отсюда следует, что система обеспечения национальной безопасности должна включать подсистему механизмов и средств содействия достижению высокого качества жизни населения.

На каждом этапе общественных трансформаций в социальной политике государства появляются определенные приоритеты. Сегодня к ним относят регулирование доходов населения, борьбу с бедностью, занятость населения, социальную защиту безработных, развитие социального партнерства. Выделенные приоритеты являются основой для формирования важнейших направлений социальной защиты и социально-экономического развития страны, базовыми компонентами системы обеспечения национальной безопасности.

Исследуя субъективные факторы качества жизни и их влияние на защищенность национальных интересов, необходимо отметить, что усиление хаотичности развития социальной системы в общественном сознании детерминирует распространение иррациональных ценностей, мотивов и потребностей, целей и действий (синергетический принцип дезорганизации), что проявляется в резкой поляризации мнений и оценок, в доминировании нереалистичных надежд, фантазий, утопических идеалов относительно возможных сценариев будущего развития общества, в разрастании в различных группах, особенно в люмпенизированных, мистического мировоззрения, а также в усилении восприятия радикальных и деструктивных призывов. В России эта зависимость проявляется в нестабильности общественного мнения, смене настроений, возможности манипулирования общественными ценностями, формировании общего скепсиса и недоверия к институтам. Такая ситуация может привести к тому, что социальное напряжение достигнет своего критического уровня и обязательно проявится в массовых беспорядках. Более серьезными последствиями могут стать сбои в функционировании воспроизводственных механизмов общества, распространении социальной аномии, в которую будут вовлекаться все новые социальные слои. Как следствие, для значительной части населения станет нормой девиантное поведение, что крайне негативно повлияет на состояние защищенности национальных интересов (Федорова, Минченкова, 2017: 53).

Одним из определяющих факторов качества жизни является уровень доходов населения. Аифференциация доходов населения характеризует степень неравномерности распределения материальных и духовных благ между людьми и формируется в результате воздействия занятости, отдельных демографических факторов (количество работающих в семье, детей, иждивенцев), уровня социальных льгот и т. п. Этот показатель характеризует социально-политический климат общества, а также степень социально-экономического развития страны.

С точки зрения защищенности национальных интересов России ситуация с показателями социально-экономического расслоения населения на сегодня достаточно угрожающая. Сейчас в структуре российского общества усиливаются процессы социальной дезинтеграции, которые определяются качественными изменениями в структуре доходов, отношениях по поводу перераспределения собственности и власти, что, в свою очередь, обусловливают существенные изменения уровня благосо- 
стояния различных групп населения, их норм и ценностей, а также их самоидентификации. Сравнительная оценка объемов накопленного имущества в полярных группах показала, что около 85\% домохозяйств России характеризуются нулевым потенциалом и почти $10 \%$ владеют им на низком уровне. Отсюда можно сделать вывод о гипертрофированных, весьма опасных для национального развития российского социума тенденциях.

Чрезмерная дифференциация доходов в России тесно связана с проблемой бедности, которая имеет собственные специфические признаки. Этому явлению предшествовали серьезные макроэкономические процессы предыдущих десятилетий, обеднение широких слоев общества развивалось на фоне значительного расслоения. Бедными стали люди, которые в свое время честно работали и были законопослушными гражданами. Феномен бедности занятого населения является свидетельством нарушений принципиальных основ формирования стоимости рабочей силы и системы оплаты труда. На сегодня в России около 10\% населения находится в состоянии застойной бедности, которая характерна для современного этапа социально-экономического развития страны и является наиболее опасной для стабильности социально-экономической системы России. Застойная бедность и бедность работающих выделяются как специфические признаки бедности в России (Федорова, Минченкова, 2016: 89).

Взаимообусловленное влияние бедности и национальной безопасности базируется на том, что бедность, будучи следствием дисгармонии экономической системы, формирует ряд специфических угроз. Так, криминализация экономики и общества приводит к реализации интересов криминальных структур, которые не имеют ничего общего с интересами легально действующих субъектов хозяйствования. В результате проигрывают все, кроме криминальных структур и коррумпированных чиновников. Расслоение и нестабильность общества - очевидные угрозы для нормального функционирования экономики страны - при условии тотальной бедности ни один экономический агент не может чувствовать себя защищенным. В свою очередь, состояние незащищенности социально-экономической системы усиливает бедность населения страны и производит факторы, углубляющие бедность.

\section{СПИСОК АИТЕРАТУРЫ}

Федорова, Н. В., Минченкова, О. Ю. (2016) Экономика труда : учебник для бакалавриата. М. : КноРус. 325 с.

Федорова, Н. В., Минченкова, О. Ю. (2017) Управление персоналом : учебник. М. : КноPyc. 536 c.

Aата поступления: 10.11.2018 2.

\section{QUALITY OF LIFE IN THE SYSTEM OF PRIORITIES \\ OF SAFE NATIONAL DEVELOPMENT \\ O. Y. MINCHENKOVA \\ MOSCOW UNIVERSITY FOR THE HUMANITIES}

The article considers the role of quality of life in the system of priorities of safe national development. Priorities of social policy of the state are allocated. The volume of accumulated property in the polar groups and its potential was estimated. The specific signs of poverty in Russia are defined.

Keywords: quality of life; factors of quality of life; national security; educational program; social policy; development priorities 


\section{REFERENCES}

Fedorova, N. V. and Minchenkova, O. Yu. (2016) Labor Economics : textbook for undergraduate. Moscow, KnoRus. 325 p. (In Russ.).

Fedorova, N. V. and Minchenkova, O. Yu. (2017) Personnel Management : textbook. Moscow, KnoRus. 536 p.

Submission date: 12.12.2018.

Минченкова Ольга Юрьевна - доктор экономических наук, профессор Московского гуманитарного университета. Адрес: 111395, Россия, г. Москва, ул. Юности, д. 5, корп. 2. Тел.: +7 (499) 374-70-13. Эл. aspec: kafedra612@mail.ru

Minchenkova Olga Yurievna, Doctor of Economic sciences, Professor, Professor of the Department of Management, Moscow University for the Humanities. Postal address: 5 Yunosti St., Moscow, 111395, Russia. Tel.: +7 (499) 374-70-13.E-mail: kafedra612@mail.ru 